Jurnal Pengajian Melayu - JOMAS, Jilid 32(1), 2021: 69-88

\title{
PERANAN DAN SUMBANGAN NIK RAHIMAH NIK IDRIS DALAM BIDANG SULAMAN KELINGKAN
}

\author{
(THE ROLE AND CONTRIBUTION OF NIK RAHIMAH NIK IDRIS
}

IN 'KELINGKAN': A MALAY TRADITIONAL EMBROIDERY)

\author{
Norhayati Ab. Rahman \\ Univeriti Malaya, Kuala Lumpur \\ Malaysia \\ yati@um.edu.my \\ Maizira Abdul Majid \\ Univeriti Malaya, Kuala Lumpur \\ Malaysia \\ maizira@um.edu.my
}

Received: 21 September 2020; Accepted: 8 April 2021

\begin{abstract}
The 'kelingkan' embroidery is a traditional Malay art passed on from generation to generation. The art received the highest recognition from female nobility and aristocrats who wore it to important events in olden times. However, the art of embroidering 'kelingkan' faces extinction due to a decrease in demand from the community because of its high cost and shortage of skilled 'kelingkan' embroiderers. Moreover, there is a lack of reference materials and documentation of 'kelingkan'; hence it is not widely known today. This paper, therefore, aimed to introduce a prominent 'kelingkan' practitioner from Kelantan named Nik Rahimah Nik Idris. The research delved into her role and contribution towards 'kelingkan' embroidery, specifically in Kelantan and Malaysia in general. Researchers conducted a literature review and then fieldwork to interview 'kelingkan' embroiderers. The results were then evaluated through content analysis. Findings showed that Nik Rahimah is indeed an important figure in the art of 'kelingkan' as she was a royal embroiderer, 'kelingkan' demonstrator, expert and promoter of the art in Malaysia and abroad. As such, she has made a significant contribution in upholding and preserving the art of 'kelingkan' embroidery.
\end{abstract}

Keywords: role, embroiderer, kelingkan, Kelantan. 


\begin{abstract}
Abstrak
Sulaman kelingkan merupakan seni tradisi warisan masyarakat Melayu sejak zaman berzaman dan pernah mendapat tempat tertinggi dalam kalangan wanita istana, kaum bangsawan dan dipakai dalam majlis-majlis penting dalam negara. Namun, pada hari ini penggunaan kelingkan mengalami masalah kepupusan kerana kurang mendapat sambutan masyarakat disebabkan harganya yang mahal dan masalah kekurangan penyulam mahir. Ketiadaan bahan rujukan atau dokumentasi tentang penyulam dan sulamannya juga menyebabkan generasi hari ini semakin tidak mengenali seni tradisi warisan ini. Tulisan ini bertujuan untuk memperkenalkan seorang tokoh penyulam ulung sulaman kelingkan di negeri Kelantan, iaitu Nik Rahimah Nik Idris, di samping memperlihatkan peranan dan sumbangan beliau dalam sulaman kelingkan di negeri Kelantan khususnya dan negara umumnya. Kajian ini menggunakan kaedah kajian kepustakaan dan kajian lapangan dengan menemu bual penyulam kelingkan di daerah terbabit. Kaedah analisis kandungan pula digunakan bagi menilai sumbangan tokoh penyulam. Dapatan kajian menunjukkan tokoh Nik Rahimah Nik Idris memainkan peranan dan sumbangan sebagai penyulam diraja, tenaga pengajar, pakar rujuk, dan sebagai promoter seni sulaman di dalam dan luar negara. Justeru, beliau telah memberikan sumbangan besar dalam memartabatkan dan memelihara seni sulaman kelingkan.
\end{abstract}

Kata Kunci: peranan, tokoh penyulam, kelingkan, Kelantan.

\title{
Pengenalan
}

Kajian pemetaan berjudul kelingkan "Jejak Sulaman Kelingkan di Malaysia dan Indonesia" (Suhana Sarkawi dan Norhayati Ab. Rahman, 2016, p. 45-69) menunjukkan bahawa kewujudan dan penyebaran seni sulaman kain selendang atau selayah berbenang logam emas atau perak yang sangat unik ini didapati berlaku secara meluas di rantau Kepulauan Melayu. Kemasukan bahanbahan seperti benang, pita logam emas dan perak dari China dan India (Maxwell, 1994, p.315) pada awal abad ke-10 telah memeriahkan istana-istana Melayu di kawasan Kepulauan Melayu. Malah, dalam teks-teks kesusasteraan Melayu tradisional terdapat pemerihalan kekayaan sesebuah kerajaan yang dilambangkan dengan 'busana yang bergemerlapan itu' atau ungkapan 'maka dipakailah persalinan keemasan, berbunga pekan atau bersuji benang emas' (Siti Zainon, 2010). Pemakaian busana Melayu seperti tidak lengkap jika tidak mengenakan tudung atau selendang kelingkan di atas bahu atau kepala wanita tanpa mengenal taraf dan darjat. Perbezaan antara nilainya ialah kepadatan atau heavy or light (Johnstone, 1985, p. 5) sulaman benang pita emas dan perak pada kain selendang atau selayah tersebut. Semakin penuh dan halus sulaman benang pita emas atau perak pada tudung atau selendang, semakin tinggi kemampuan si pemakai atau status keluarganya. Penyebaran ajaran Islam dan pengaruh budaya sulaman benang emas yang dibawa oleh para pedagang Timur Tengah, Turki dan Mughul India ke alam Melayu khususnya Acheh, Johor dan Brunei merancakkan lagi keindahan seni pada corak dan sebaran sulaman busana Melayu (Maxwell, 1994, p. 316).

Penyelidikan awal mengenai sulaman kelingkan ${ }^{1}$ di beberapa buah negeri lain di Malaysia 1 Menurut Azran (2010, p. 5), istilah keringkam atau kelingkan ini berasal daripada perkataan Bali, iaitu 'Keling' yang membawa maksud sejenis fabrik dan 'kam' atau 'kham' bermaksud cantik, manakala Azah Aziz (2009, p. 128) menyatakan kata 'keringkam' atau 'kelingkan' berasal daripada perkataan Perancis, iaitu 'Clinquant'. 
seperti Selangor dan Sarawak telah dilakukan. Walau bagaimanapun, kajian mengenai sulaman kelingkan masih belum banyak dijalankan di negeri Kelantan. Kajian pemetaan awal oleh Suhana Sarkawi dan Norhayati Ab. Rahman (2016) yang dilakukan sebelumnya menunjukkan lokasi kewujudan dan pembuatan sulaman tudung berbenang emas atau perak tersebut di beberapa negeri di Malaysia, dan perbezaan istilah mengikut negeri tertentu. Misalnya, tudung 'keringkam' merupakan istilah yang digunakan untuk merujuk pada tudung kelingkan yang disulam di Kuching, Sarawak, manakala tudung 'kelingkam' atau 'kelubung kelengkang' adalah merujuk pada tudung kelingkan yang di negeri Kelantan. ${ }^{2}$ Di negeri Selangor pula, istilah yang digunakan ialah tudung 'kelingkan', manakala istilah 'terekat terekam' pula merujuk pada tudung kelingkan di negeri Terengganu.

Hasil tinjauan awal juga menunjukkan bahawa warisan seni khazanah Melayu ini pernah mendapat tempat tertinggi dalam kalangan wanita istana, kaum bangsawan dan diperagakan pada majlis-majlis penting tertentu di beberapa buah negeri di Malaysia termasuk Kelantan. Menurut Nik Rahimah Nik Idris (2020), pada hari ini kelingkan telah mengalami masalah kepupusan, kerana kurang mendapat sambutan masyarakat. Kekurangan para penyulam mahir di negerinegeri yang mempunyai tradisi ini juga agak membimbangkan. Kurangnya sambutan masyarakat pada hari ini ialah disebabkan harga tempahannya yang mahal. Proses pembuatannya memerlukan bahan-bahan yang mahal dan proses penyulamannya mengambil masa yang lama. Mengulas mengenai keistimewaan sulaman kelingkan, Nik Rahimah Nik Idris memberitahu bahawa beliau menggunakan logam perak tulen yang dipanggil sebagai kelingkan dan nama sulaman tersebut diambil sempena nama logam tersebut. Menurut beliau juga, sulaman kelingkan bukan hanya tertumpu kepada tudung selendang sahaja (yang paling popular), tetapi sulaman tersebut juga boleh dibuat pada peralatan lain seperti baju, bantal, kipas dan alatan perkahwinan. ${ }^{3}$

Benang logam yang digunakan dalam pembuatan kelingkan terdiri daripada benang logam pipih yang disadur emas, perak atau tembaga. Benang ini perlu dijaga rapi agar tidak rosak atau patah. Harga seikat benang logam adalah kira-kira RM170, sementara jarum yang digunakan untuk membuat kelingkan ditempah khas dan lebihan benang dikumpul, kemudian dileburkan sebelum dibentuk menjadi jarum. Proses penyulaman kelingkan juga mengambil masa yang lama. Dalam tempoh sebulan (bergantung kepada taburan motif sulamannya), hanya kira-kira sehelai atau dua helai kain kelingkan sahaja dapat disiapkan. Memandangkan bahan-bahan pembuatannya yang mahal dan proses penyulamannya yang lama, maka harga minimum sehelai kelingkan ialah lebih kurang RM2500 sehelai dan boleh mencecah sehingga puluhan ribu ringgit bergantung kepada permintaan pelanggan. Selain itu, masalah kekurangan penyulam mahir juga menyebabkan sulaman kelingkan jarang dihasilkan. Walau bagaimanapun, masih terdapat sebilangan kecil pengamal (penyulam) yang masih aktif sehingga hari ini di negeri-negeri tertentu di Malaysia, termasuklah di Kelantan. Oleh itu, penulisan makalah ini dihasilkan bagi tujuan memperkenalkan tokoh penyulam ulung di negeri Kelantan, di samping berhasrat untuk mendokumentasi, memelihara, dan melestarikan seni busana warisan tradisi masyarakat Melayu agar tidak pupus sepenuhnya.

2 Rujuk makalah jurnal bertajuk "Jejak Sulaman Kelingkan di Malaysia dan Indonesia” oleh Suhana Sarkawi dan Norhayati Ab. Rahman (2016, p. 45-69) dalam Jurnal Pengajian Melayu, Universiti Malaya, Jil. 27.

3 Lihat Zubaidah Ibrahim. (2015). "Nik Rahimah mahu kelingkam dikenali” dalam akhbar KOSMO, 30 Disember, p. 21-13.

e ISSN 2735 - 1904

https://doi.org/10.22452/JOMAS.vol32no1.5 
Usaha mendokumentasi adat dan budaya ini adalah penting dan berharga kepada masyarakat negeri Kelantan khususnya dan seluruh masyarakat umumnya. Penulisan makalah ini memperkenalkan sulaman kelingkan yang menjadi tradisi warisan masyarakat Kelantan sejak zaman berzaman dan untuk memperkenalkan penyulam kelingkan yang sudah semakin pupus pada hari ini. Hal ini memandangkan tokoh penyulam pada hari ini sudah lanjut usia dan penyulam muda pula tidak dilatih secara berkala. Kajian dan dokumentasi tentang penyulam, jenis-jenis sulaman dan hubungannya dengan pihak istana serta masyarakat umum adalah sangat penting. Selain itu, segala dokumentasi tentang aktiviti sulaman kelingkan yang didokumentasi oleh pihak Muzium Negeri Kelantan sebelum ini juga telah musnah akibat Banjir Kuning yang melanda negeri Kelantan pada tahun 2014. ${ }^{4}$ Tidak ada sebarang dokumentasi mengenai penyulam dan kelingkan di Muzium Negeri Kelantan pada hari ini untuk dijadikan sebagai rujukan oleh para pengkaji atau masyarakat umum yang berminat dengan sulaman warisan tradisi ini.

Di samping itu, kajian ini juga sebagai usaha untuk menyebarkan maklumat dan pengetahuan tentang khazanah yang menjadi sebahagian daripada warisan jati diri masyarakat, yang didukung oleh istana dan rakyat negeri Kelantan sejak sekian lama. Atas kesedaran itu, penulisan ini bertujuan melestarikan kembali khazanah warisan Melayu yang begitu sinonim dengan adat dan budaya masyarakat Kelantan. Tudung sulaman kelingkan ini pada awalnya hanya dipakai oleh kerabat diraja dan kaum bangsawan, namun kini pemakaiannya juga oleh orang kebanyakan khususnya pada majlis tertentu seperti majlis pertunangan, khatam al-Quran, perkahwinan dan lain-lain. Selain itu, sulaman kelingkan juga telah dimodenkan dan tidak terhad kepada tudung sahaja, sebaliknya disulam pada pelapik dulang, tampuk bantal, malah turut dipakai sebagai layah bagi pengantin perempuan. Warisan seni busana tradisi ini telah mendapat perhatian daripada pihak istana negeri Kelantan kerana melambangkan keagungan adat dan budaya yang dimiliki oleh masyarakat Kelantan daripada golongan atasan kepada golongan rakyat jelata.

\section{Objektif Kajian}

Kajian ini mempunyai objektif untuk memperkenalkan Nik Rahimah Nik Idris sebagai tukang ulung sulaman kelingkan negeri Kelantan serta memperlihatkan peranan dan sumbangan Nik Rahimah Nik Idris dalam kegiatan sulaman kelingkan di negeri Kelantan dan negara.

\section{Kaedah Penyelidikan}

Bagi tujuan pemerolehan data, kajian ini menggunakan dua kaedah utama, iaitu kaedah kajian kepustakaan (library research) dan kedua kaedah kajian lapangan (fieldwork) dengan menemu bual pengamal atau pakar pemyulaman kelingkan di beberapa daerah terbabit. Bagi kajian lapangan, beberapa orang penyulam kelingkan di Kelantan telah ditemu bual, iaitu Nik Rahimah Nik Idris, dan Nik Marhamah Nik Megat di Kota Bharu, serta Puan Robitah Hashim di Pasir Mas. Di samping

4 Banjir atau bah adalah suatu fenomena yang berlaku hampir saban tahun di kawasan mudah banjir di Malaysia. Banjir di Lembangan Sungai Kelantan pada Disember 2014 yang juga dikenali sebagai Bah Kuning merupakan salah satu banjir terbesar dan terburuk dalam sejarah negara. Lihat Zulkifli Yusup dan Abdul Hamid Mar Iman (2020) Bah Kuning 2014 di Kelantan, Johor Bharu: Penerbit Universiti Teknologi Mara. 
itu, tinjauan juga dilakukan semasa pengendalian bengkel sulaman kelingkan oleh Nik Rahimah Nik Idris di Kompleks Kraf Negara, Jalan Conley Kuala Lumpur. Bagi tujuan penganalisisan data pula, kajian ini menggunakan kaedah analisis kandungan (content anylysis) untuk menilai peranan dan sumbangan tokoh penyulam Nik Rahimah Nik Idris pada peringkat negeri Kelantan, khususnya dan Malaysia amnya.

\section{Latar Tokoh dan Ketokohan Nik Rahimah Nik Idris}

Nik Rahimah binti Nik Idris telah dilahirkan pada 22 September 1941 di S/3215 Lorong Datuk Nik Jaafar, Kubang Pasu, 15300 Kota Bharu, Kelantan. Beliau mendapat pendidikan awal di Sekolah Melayu Merbau, Kota Bharu. Penglibatan beliau dalam bidang jahitan dan sulaman telah bermula sejak tahun 1956 lagi, iaitu ketika beliau berumur 15 tahun. Ketika itu, beliau memerhati arwah nenek saudaranya, iaitu Tuk Wan Noh (Nik Maimunah), yang tekun menjahit dan menyulam. Minat, kesungguhan dan usahanya dalam memerhati kegiatan menjahit dan menyulam menyebabkan beliau ingin mencubanya sendiri. Berdasarkan pemerhatian dan tunjuk ajar oleh nenek saudaranya itulah lama kelamaan beliau berkebolehan menjahit dan menyulam dengan mewarisi kemahiran tersebut. Beliau memperolehi pelbagai kemahiran seni sulaman, khususnya sulaman kelingkan adalah berdasarkan pemerhatian teliti (closed observation) terhadap proses kerja-kerja seni tersebut yang dilakukan oleh nenek saudaranya yang dipanggil beliau sebagai Tuk Wan Noh itu. Nenek saudaranya pula dikatakan mempelajari kaedah dan kemahiran menyulam kelingkan sewaktu beliau tinggal bersama keluarganya di Mekah dan berdasarkan pemerhatiannya terhadap kaedah pembuatan sulaman pada tudung-tudung kepala wanita di Turki. Moyang Nik Rahimah Nik Idris (ibu nenek saudaranya) tersebut berasal dari Pattani, Thailand dan mempunyai hubungan persaudaraan dengan tokoh ulama terkenal, iaitu Syeikh Daud Abdullah al-Patani. ${ }^{5}$ Syeikh Daud Abdullah al-Fatani (1804-1843) merupakan seorang tokoh ulama terkenal berasal dari Patani dan berperanan besar dalam penyebaran agama Islam di Nusantara melalui penulisan kitab-kitab agama dan pengajaran di sekolah-sekolah pondok. Beliau hidup hampir sezaman dengan tokoh Abdullah Munsyi (1798-1854) dan tokoh Raja Ali Haji (1808-1873). Namun ketiga-tiga tokoh ini menguasai bidang penulisan yang berlainan, iaitu Syeikh Daud dalam penulisan kitab agama, Abdullah Munsyi menulis kisah perjalanan (travelog atau pencatat zamannya) dan Raja Ali Haji pula terkenal dalam penulisan karya historiografi (sastera sejarah).

Menurut Nik Rahimah Nik Idris (2020), beliau mengikut jejak langkah nenek saudaranya yang terkenal dalam bidang sulaman kelingkan. Beliau telah diperkenalkan kepada pihak istana oleh sepupunya, Nik Zabedah binti Nik Mat kerana kemahirannya dalam bidang sulaman kelingkan. Suami sepupunya itu merupakan tukang jahit kepada keluarga diraja di istana Kelantan. Semenjak itu, Nik Rahimah Nik Idris telah diberi tanggungjawab sebagai tukang jahit kepada Raja Perempuan Kelantan, iaitu Almarhum Tengku Zainab Almarhum Tengku Muhammad Petra. Kehalusan dan kekemasan kerja tangan beliau amat dikagumi oleh baginda Raja Perempuan (Nik Rahimah Nik Idris, 2020). Memandangkan kegiatan sulaman kelingkan telah dipelajari sejak remaja, maka proses penyulaman begitu dekat dengan jiwanya. Menurut Nik Rahimah Nik Idris, 5 Maklumat diperolehi sewaktu temubual dengan Nik Rahimah Nik Idris di rumahnya, di Taman Uda Murni, Kota

Bharu pada 5 Februari 2020, jam 5:00 petang. 
"Sulaman kelingkan tidaklah terlalu sukar kerana sejak kecil saya sudah biasa memerhatikan nenek melakukan kerjakerja kesenian dan sudah sebati dalam diri saya," jelas wanita yang berasal dari Kubang Pasu, Kota Bharu itu"6.

Nik Rahimah Nik Idris bukanlah calangcalang penyulam kerana darah seni yang mengalir dalam dirinya menjadikan anak bongsu daripada tujuh beradik itu sangat berjasa dalam memartabatkan seni warisan tersebut. Neneknya sendiri, iaitu Nik Aminah Nik Mat pula berkebolehan dalam bidang seni anyaman, tenunan dan banyak lagi jenis seni kraftangan, selain juga sebagai penyulam kelingkan. Pendek kata, beliau memang dilahirkan dalam keluarga seni kerana hampir semua ahli keluarganya berkebolehan dalam pelbagai seni seni warisan tradisi. Selain sulaman kelingkan, Nik Rahimah Nik Idris juga berkemahiran membuat tekatan pakupaku, sulaman ayak, jahitan manik, pakaian, bunga dan kaitan (jarum satu dan dua), serta peralatan singgahsana diraja Kelantan.

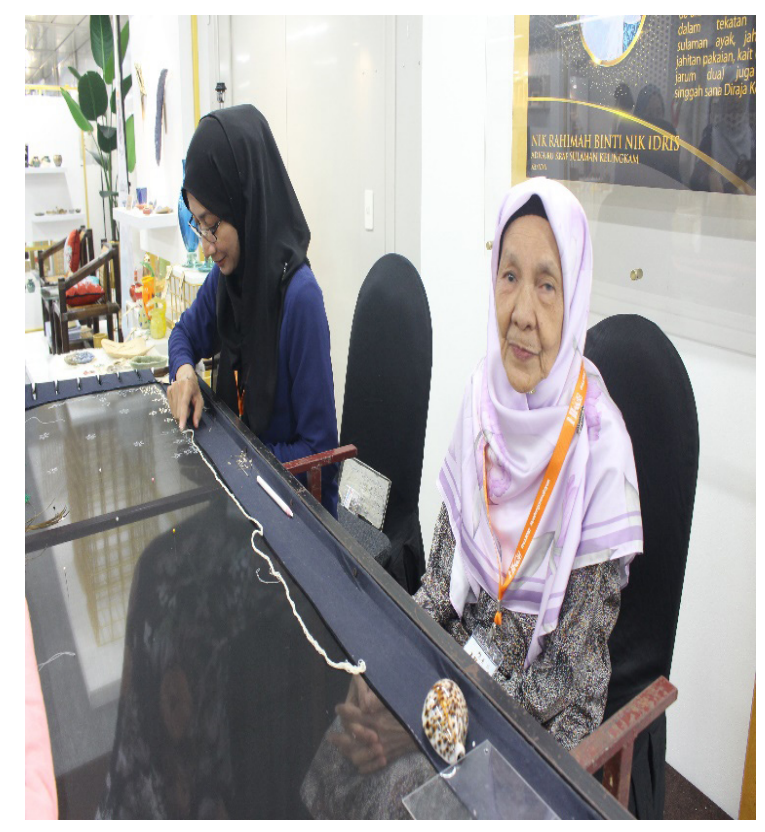

Gambar 1: Adiguru Nik Rahimah Nik Idris ketika ditemui membuat demostrasi kelingkan pada Minggu Kraf di Kompleks Kraftangan, Jalan Conley pada 6 Mac 2020.

Menurut Nik Rahimah Nik Idris (2020), kemahiran seni yang hampir sama turut diwarisi oleh dua orang adik-beradiknya, termasuk abangnya Nik Mohamad Isa Nik Idris yang juga berkemahiran tinggi dalam menyulam kelingkan, sementara ayahnya sendiri, iaitu Nik Idris bin Datuk Nik Jaafar memiliki kemahiran seni kraftangan dalam bidang ukiran kayu. Ukiran kayu ialah seni kraftangan yang telah lama wujud dalam kalangan masyarakat Melayu di Kelantan, Terengganu, masyarakat etnik Sabah dan Sarawak serta masyarakat Orang Asal. Walau bagaimanapun, kini hanya Nik Rahimah seorang yang masih aktif menyulam memandangkan abangnya, iaitu Nik Mohamad Isa

6 Lihat Zubaidah Ibrahim. (2015). "Nik Rahimah mahu kelingkam dikenali" dalam akhbar KOSMO, 30 Disember, p. 21-13. 
Nik Idris telah meninggal dunia dan kakaknya pula sedang uzur. Selain itu, kepandaian seni sulaman kelingkan tersebut turut diwarisi oleh cucu saudaranya, Nik Marhamah Nik Megat dan cicitnya Nik Nurul Amalina Nik Mohd Nizam.

Walaupun beliau sudah semakin menakah ke usia tua, namun semangat dan kecintaannya terhadap sulaman kelingkan, Hajah Nik Rahimah Nik Idris masih lagi aktif meneruskan khidmatnya terutama dalam pembuatan selendang kelingkan yang kebanyakannya ditempah oleh kerabat-kerabat diraja dan isteri-isteri pembesar negeri. Memandangkan usia yang semakin lanjut, kegiatan tersebut kini dilaksanakan dengan bantuan oleh penyulam muda asuhannya, iaitu Nik Marhamah Nik Megat yang juga merupakan cucu saudaranya. Nik Marhamah Nik Megat adalah satu-satunya pewaris utama yang masih ada dan mewarisi segala kemahiran dan kehalusan kraftangan Nik Rahimah Nik Idris dalam bidang sulaman kelingkan. Kehalusan, kekemasan dan keindahan hasil sulaman kelingkannya persis menghampiri kemahiran dan kehalusan sulaman Nik Rahimah sendiri. Nik Marhamah Nik Megat sudah membina nama dan mempunyai kepakaran dalam kegiatan penyulaman kelingkan sendiri. Beliau juga banyak menerima tempahan pembuatan kelingkan. Nik Marhamah Nik Megat juga telah terlibat secara solo atau bersama Nik Rahimah Nik Idris dalam banyak pameran dan demostrasi penyulaman kelingkan yang dianjurkan oleh pelbagai institusi kraf di negara ini. Kemuncaknya ialah pada 14-16 September 2020, apabila Nik Marhamah Nik Megat telah dijemput oleh Malaysian Craft Council (MCC) bagi membuat demostrasi sulaman pada Majlis Kelantan Exchange 2020 yang berlangsung di Hotel Grand Riverview Kota Bharu. Dalam majlis tersebut, Nik Marhamah Nik Megat dikurniakan Anugerah Sanggar Mustika. Sementara itu, Nik Rahimah pula kini lebih fokus kepada jemputan untuk mengadakan demonstrasi dan memberi tunjuk ajar dalam pelbagai aspek teknik dan motif sulaman kelingkan dengan bantuan Nik Marhamah Nik Megat.

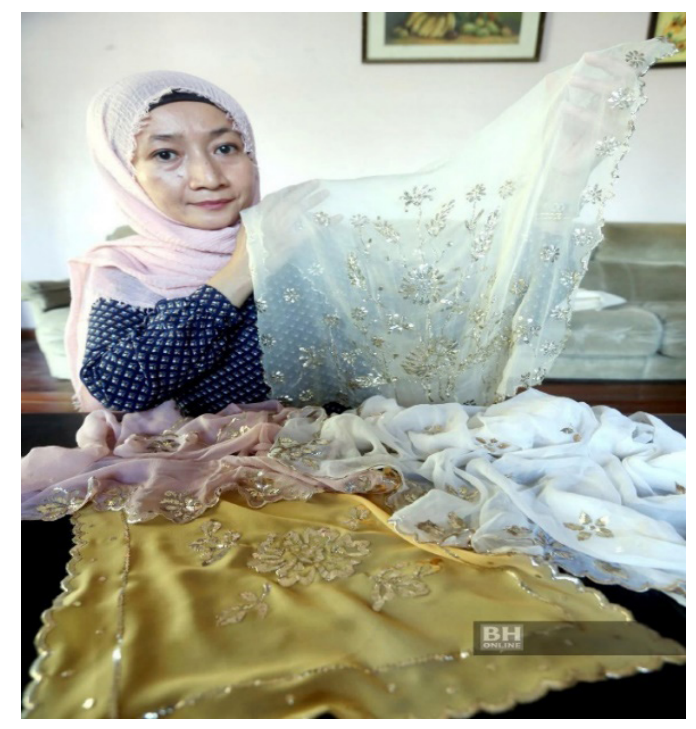

Gambar 2: Nik Marhamah Nik Megat, pembantu Nik Rahimah Nik Idris

(Sumber: Berita Harian Online, pada 22 Julai 2016) 


\section{Peranan dan Sumbangan Nik Rahimah Nik Idris dalam Seni Kraftangan Kelingkan}

Sebagai seorang tokoh yang telah mendapat pengiktirafan di dalam dan luar negara, Nik Rahimah Nik Idris telah memberi sumbangan besar dalam memartabatkan dan memelihara seni sulaman kelingkan supaya terus terpelihara dan kekal sebagai seni warisan negara. Antara sumbangan yang telah dilakukan oleh beliau dalam memartabatkan seni kraftangan kelingkan ialah menjadi penyulam diraja sekaligus memastikan seni sulaman kelingkan terus terpelihara dan berada pada kedudukan yang tersendiri sebagai kraftangan warisan negara. Beliau turut dijemput menjadi pengadil dalam pertandingan seni sulaman kelingkan, menjadi tenaga pengajar dan pakar rujuk kepada masyarakat yang berminat mempelajari serta mengetahui dengan lebih mendalam berkaitan seni kraftangan sulaman kelingkan. Peranan dan sumbangan beliau dapat dibahagikan kepada beberapa bahagian utama, iaitu:

\section{Peranan dan Sumbangan Secara Individu}

Di Kelantan, sulaman kelingkan pernah mendapat kedudukan yang tinggi kerana mendapat tempat istimewa oleh pihak istana. Hal ini demikian memandangkan raja-raja perempuan negeri Kelantan merupakan pemakai utama tudung sulaman kelingkan. Kemahiran yang dimiliki oleh Nik Rahimah Nik Idris telah meletakkan dirinya sebagai Penyulam Diraja Kelantan yang terkenal. Dengan kemahiran tinggi dan kehalusan seni sulaman yang dimilikinya, Nik Rahimah Nik Idris telah berkhidmat dengan Raja Perempuan Kelantan sejak tahun 1960-an. Pada peringkat awal, beliau mula berkhidmat sebagai tukang jahit untuk Raja Perempuan Kelantan, iaitu Al-Marhumah Raja Perempuan Zainab Dua sehinggalah baginda Raja Perempuan mangkat pada 10 Januari 1993 di Istana Negeri, Kubang Kerian (ketika berusia 75 tahun). Ketika Al-Marhumah Raja Perempuan Zainab Dua masih hidup, perkhidmatan Nik Rahimah Nik Idris mendapat pengiktirafan tinggi daripada Raja Perempuan apabila beliau sentiasa dibawa mengikut baginda sehingga ke luar negara. Nik Rahimah juga dibawa tinggal bersama-sama baginda di Istana Negara sewaktu baginda menjadi Raja Permaisuri Agong. Setelah kemangkatan baginda, Nik Rahimah Nik Idris kemudian menyambung perkhidmatannya sebagai tukang jahit tudung sulaman kelingkan, manik dan labuci untuk pakaian Raja Perempuan Kelantan seterusnya, iaitu Permaisuri Tengku Anis.

Perkhidmatan beliau kepada raja-raja perempuan Kelantan telah membuktikan kehalusan dan keindahan hasil-hasil kerja sulaman beliau sehingga raja-raja perempuan Kelantan hanya mahukan hasil kerja bermutu dan halus daripada hasil kerja tangan beliau sahaja. Pernah satu ketika apabila Nik Rahimah tidak sempat untuk menyiapkan tempahan sulaman yang banyak untuk Raja Perempuan, beliau telah meminta bantuan abangnya yang juga mahir dalam seni sulaman kelingkan untuk membantunya. Walau bagaimanapun, hasil kerja tangan abangnya itu dapat dicam oleh baginda Raja Perempuan. Baginda cukup mengenali kehalusan dan keindahan hasil seni Nik Rahimah sahaja. ${ }^{7}$ Selain itu, beliau turut menerima tempahan khas sulaman kelingkan daripada kerabat diraja dari negeri lain seperti Selangor, Perlis, Johor, Terengganu dan Perak serta isteriisteri pembesar negara.

$7 \quad$ Maklumat diperolehi sewaktu temu bual dengan Nik Rahimah Nik Idris di rumahnya, di Taman Uda Murni, Kota Bharu pada 5 Februari 2020, jam 5:00 petang.

e ISSN 2735 - 1904

https://doi.org/10.22452/JOMAS.vol32no1.5 


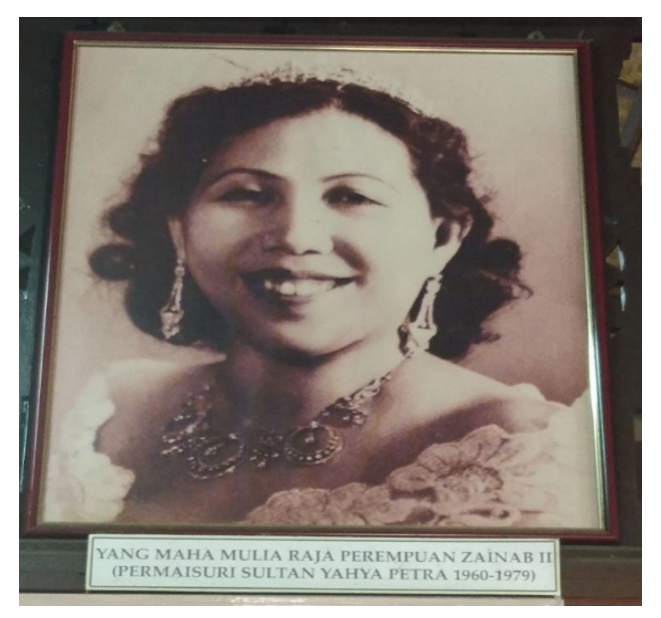

Gambar 3: Yang Maha Mulia Raja Perempuan Zainab II, Permaisuri Sultan Yahya Petra 1960-1979.

(Sumber: Muzium Kraftangan Kelantan)

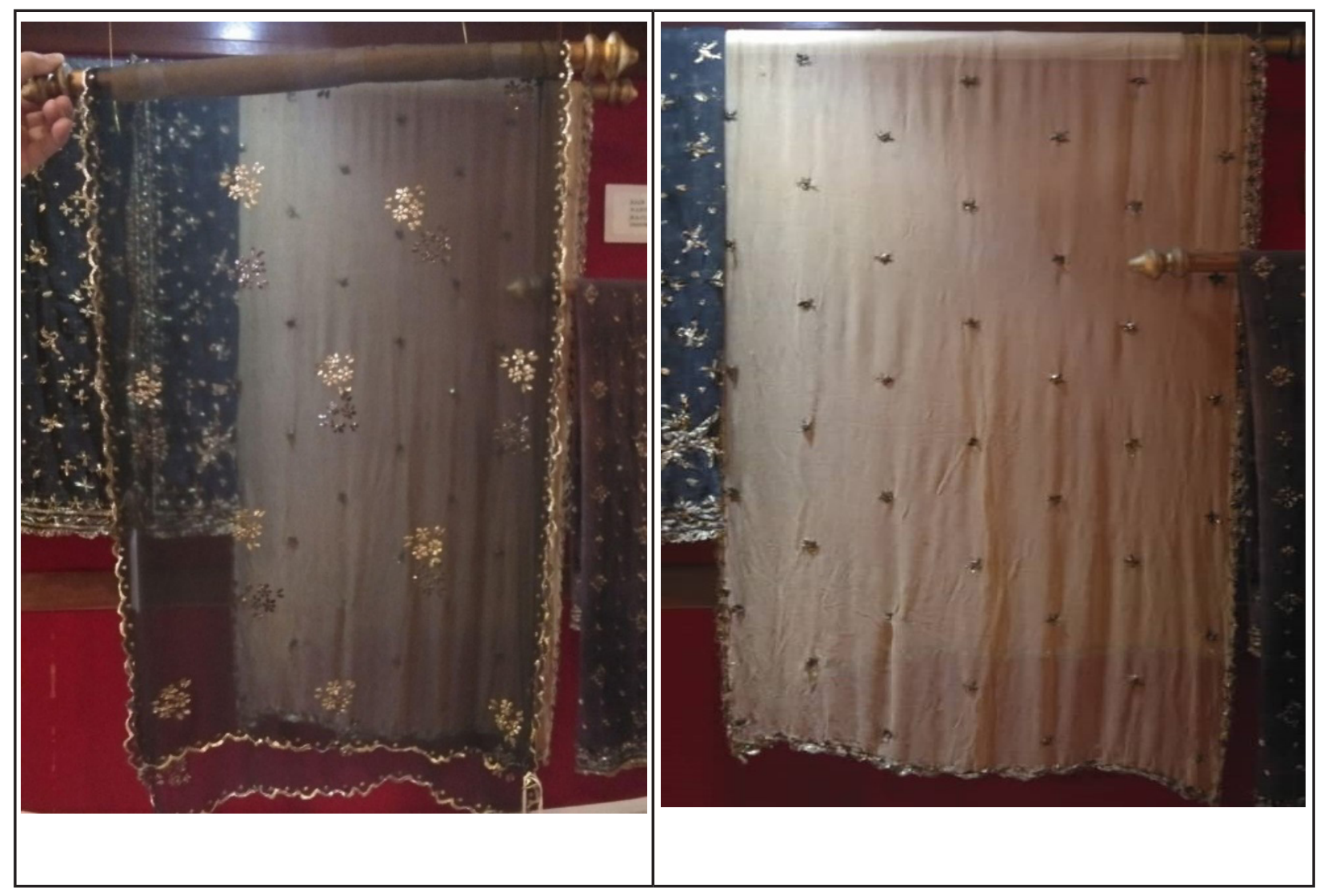

Gambar 4: Antara koleksi Tudung Kelengkan Raja Perempuan Kelantan

(Sumber: Muzium Kraftangan Negeri Kelantan)

Catatan sejarah peribadi yang penting bagi Nik Rahimah Nik Idris pada tahun 1970- 
an apabila beliau dititahkan oleh Almarhum Sultan Yahya Petra untuk membuat seni sulaman (tekatan) terhadap sepasang kasut (sandal) bagi tujuan dihadiahkan kepada raja Thailand, iaitu Raja Bumiphol Aduyadev. Kerja sulaman tersebut merupakan antara sumbangan penting dan merupakan pengiktirafan tinggi kepada Nik Rahimah kerana diberi penghormatan untuk berkhidmat membantu baginda Sultan Kelantan semasa menjalinkan hubungan diplomatik dengan Raja Thailand pada ketika itu.

Selain itu, hasil-hasil kerja seni beliau juga mendapat perhatian dari luar negeri Kelantan. Kerabat-kerabat diraja tertarik dengan kehalusan, kekemasan dan keindahan sulaman oleh Nik Rahimah Nik Idris. Beliau mendapat permintaan untuk menjahit kelengkapan pakaian seperti selendang bersulam kelingkan dengan dibantu oleh anaknya, Engku Rafidah Engku Chik (anak beliau meninggal dunia pada tahun 2013 akibat kanser paru-paru) untuk kegunaan Permaisuri Sultan Selangor Tengku Ampuan Rahimah Alhajjah binti Almarhum Sultan Abdul Aziz Langkat, Permaisuri Sultan Perlis yang ke-2, Tuanku Tengku Fauziah binti Almarhum Tengku Abdul Rashid dan juga menjahit selendang bersulam kelingkan untuk keperluan Sultanah Johor Tengku Zanariah binti Almarhum Tengku Ahmad bagi tujuan Majlis Konvokesyen Univesiti Teknologi Malaysia (UTM), Skudai. Beliau turut menerima tempahan khas sulaman kelingkan daripada kerabat diraja Terengganu, Perak dan isteri-isteri pembesar negara. Sekitar tahun 1980-an, beliau bertanggungjawab menjadi penyulam sulaman ayak untuk ibu adiguru Lim Swee Kim. Lim Swee Kim merupakan seorang tokoh kraf sulaman Nyonya dan telah diiktiraf sebagai Adiguru kraf sulaman Nyonya pada tahun 2006.

Pada tahun 1993 pula, beliau terlibat dalam penyediaan peralatan diraja untuk Muzium Adat Istiadat Diraja atau dikenali sebagai Istana Jahar di Kelantan. Muzium Adat Istiadat Diraja Kelantan telah dirasmikan oleh Al-Sultan Kelantan pada 27 Julai 1992. Muzium ini mempamerkan pelbagai jenis tekstil, alat perhiasan diri, pakaian, barang-barang tembaga untuk tontonan umum dan menjadi pusat lawatan serta tarikan pelancong dari dalam dan luar negara. Oleh kerana sulaman kelingkan merupakan antara barang perhiasan diraja, maka Nik Rahimah Nik Idris telah diberi tanggungjawab untuk menyediakan peralatan perhiasan diraja yang berasaskan sulaman kelingkan untuk dipertontonkan kepada umum. Tujuannya ialah untuk memperlihatkan seni keindahan kelingkan dan memartabatkan kedudukan seni sulaman diraja tersebut. Pada tahun yang sama, beliau juga terlibat dalam penyediaan peralatan diraja untuk dipamerkan di Muzium Istana Johor.

Seterusnya, peranan Nik Rahimah Nik Idris sebagai penyulam diraja Kelantan melayakkan beliau diberi pengiktirafan sebagai individu yang bertanggungjawab untuk menyediakan peralatan perkahwinan diraja. Peranannya sebagai penyulam dan seni sulaman kelingkan di negeri Kelantan, khususnya di istana Raja Perempuan Kelantan dapat dilihat melalui tugas yang diamanahkan kepadanya (kebanyakan tudung sulaman kelingkan milik Raja Perempuan sekarang dipamerkan di Muzium Kraftangan Negeri Kelantan). Selain di istana, kelingkan juga diberi tempat istimewa dengan pemakaiannya pada majlis-majlis rasmi seperti pertunangan dan perkahwinan di negeri Kelantan. Pada tahun 2012, beliau telah menyiapkan kelengkapan peralatan perkahwinan Diraja Kelantan dengan menggunakan kelingkan untuk keperluan pameran di Muzium Negeri Pahang. Peralatan perkahwinan tersebut dijadikan bahan pameran untuk dipertontonkan kepada pengunjung yang datang ke Muzium Negeri Pahang. 


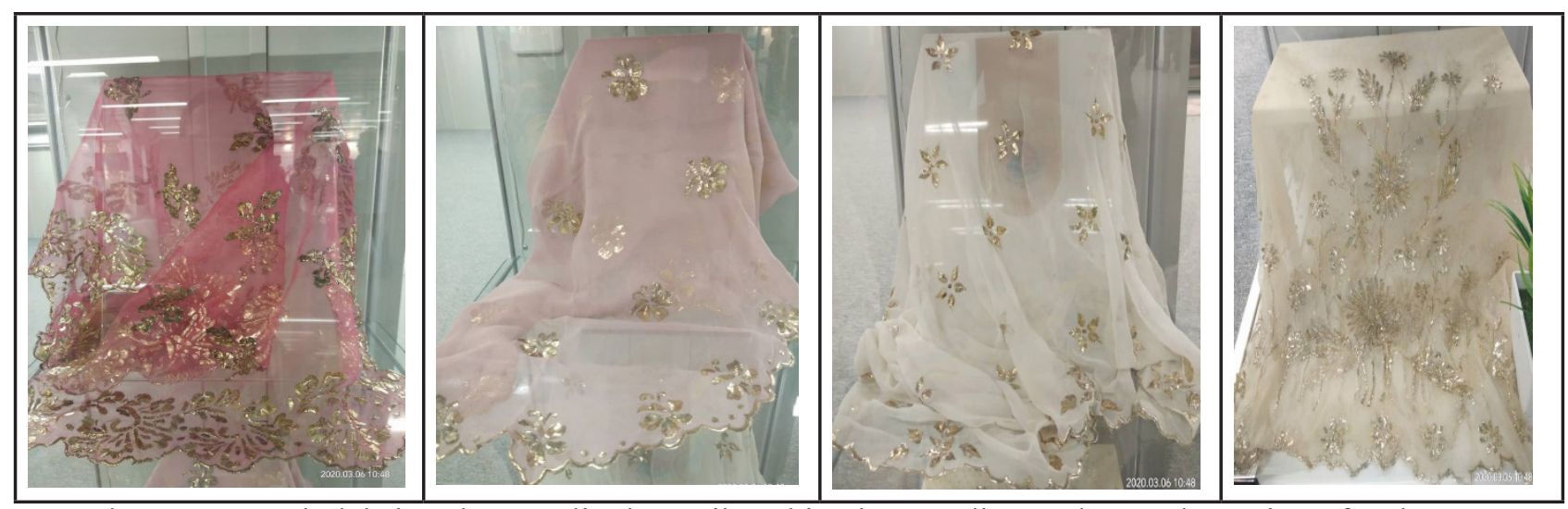

Gambar 5: Antara koleksi Tudung Kelingkan Nik Rahimah yang dipamerkan pada Hari Kraf Kebangsaan, di Kompleks Kraf, Jalan Conley pada 26 Feb-9 Mac 2020.

\section{Peranan dan Sumbangan dalam Masyarakat}

Ilmu kemahiran seni sulaman kelingkan yang diwarisi oleh beliau dari nenek moyang telah diperturunkan kepada masyarakat, khususnya generasi muda. Tujuannya adalah untuk memastikan seni warisan kelingkan dapat dilestarikan dan dipelihara untuk generasi akan datang. Bagi tujuan tersebut, beliau berperanan sebagai tenaga pengajar dan pakar rujuk untuk seni sulaman kelingkan. Pada tahun 2006 misalnya, beliau telah dijemput oleh Kraftangan Cawangan Kelantan untuk berkhidmat sebagai tenaga pengajar. Beliau bertanggungjawab untuk mengajar seni sulaman kelingkan kepada 10 orang pelajar selama enam bulan. Khidmat dan usaha sama antara Kraftangan Cawangan Kelantan dan Nik Rahimah Nik Idris sendiri bertujuan untuk mengekalkan warisan sulaman kelingkan sebagai warisan seni negara. Antara pelajar yang diajar oleh beliau melalui kelas tersebut termasuklah Puan Robitah Hashim yang kemudian turut menjadi penyulam kelingkan di Kelantan. Puan Robitah Hashim juga menyebarkan ilmunya kepada masyarakat dengan memperturunkan ilmu seni sulaman kelingkan kepada para penyulam lain. Untuk tujuan tersebut, Puan Robitah Hashim sudah pun mempunyai bengkel sulaman sendiri bertempat di Tok Uban, Pasir Mas Kelantan. 


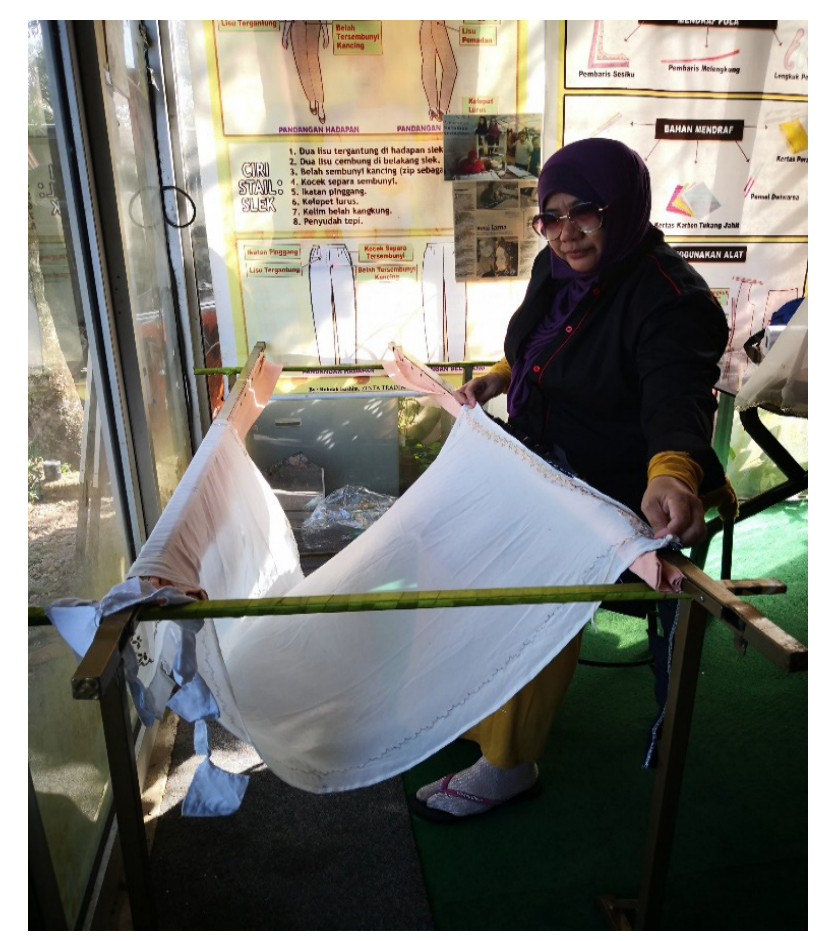

Gambar 6: Puan Robitah Hashim (pelajar Adiguru Nik Rahimah Nik Idris) ketika ditemubual di bengkel beliau.

Selain itu, Nik Rahimah Nik Idris turut berkhidmat sebagai tenaga pengajar di Yayasan Tengku Nurzahirah, Terengganu sejak tahun 2013. Sesi pembelajaran tersebut diadakan di Kota Bharu, Kelantan. Beliau telah mengadakan kelas sulaman kelingkan untuk pelajar-pelajar dari Yayasan Sultanah Nur Zahirah yang ingin mengetahui dengan lebih mendalam lagi teknikteknik sulaman tersebut. Cara itu juga membolehkan beliau dapat memperkembangkan ilmu dan kemahiran seni sulaman kelingkan yang dimilikinya kepada generasi muda dan menyebarkannya secara lebih luas, melangkaui negeri-negeri lain di Malaysia.

Antara kemahiran seni Nik Rahimah Nik Idris termasuklah sulaman kelingkan, segala jenis tekatan paku-paku, sulaman ayak, jahitan manik, jahitan pakaian, smoking (jahitan bunga), kaitan (jarum satu dan jarum dua) dan peralatan singgahsana Diraja Kelantan. Melalui kegiatan demonstrasi dan kelas-kelas yang dilaksanakan oleh Nik Rahimah, warisan sulaman kelingkan dapat diperkenalkan kepada masyarakat di Malaysia dan luar negara. Semangat dan hasrat menjadikan seni sulaman kelingkan supaya tidak lapuk ditelan zaman ini perlu dipuji kerana dapat memartabatkan kedudukan seni warisan Melayu di mata masyarakat. Selain berperanan atau berkhidmat sebagai tenaga pengajar dalam program-program yang dianjurkan oleh organisasi kerajaan dan bukan kerajaan, kemahiran yang dimilikinya telah meletakkan beliau sebagai pakar rujuk dalam seni sulaman kelingkan. Kemahiran dan kepakaran beliau tidak hanya diakui dan mendapat pengiktirafan dalam negara, malah di negara luar juga. 


\section{Peranan dan Sumbangan dalam Industri.}

Pada masa pemerintahan Sultan Ismail Petra, beliau kerap dijemput menjadi pengadil hampir setiap tahun semasa sambutan Keputraan Baginda al-Sultan Kelantan. Contohnya, beliau terlibat sebagai pengadil pertandingan sulaman, gubahan dan masakan walaupun berkhidmat sebagai Penyulam Diraja. Sebagai seorang pakar dalam bidang sulaman kelingkan, Nik Rahimah Nik Idris bukan sahaja diundang mengajar seni sulaman kelingkan di institut kemahiran, tetapi memainkan peranan penting dalam industri dengan mengadakan demonstrasi sulaman kelingkan di majlismajlis kraftangan di dalam dan luar negara melalui anjuran Perbadanan Kemajuan Kraftangan Malaysia dan muzium-muzium negeri. Perbadanan Kemajuan Kraftangan Malaysia, misalnya kerap menjemput beliau untuk menyertai demonstrasi pada Hari Kraf Kebangsaan, Promosi Kerja Kahwin, Promosi Jualan Aidilfitri di Kompleks Kraf Kuala Lumpur, Jalan Conlay, Promosi Kraf Malaysia di Pusat Jualan Kraf, Batu 2 dan lain-lain promosi anjuran Kraftangan Malaysia. Selain itu, pada bulan April 2012 beliau telah dijemput untuk mengadakan demonstrasi pada majlis perasmian pembukaan Muzium Tekstil Kuala Lumpur yang telah dirasmikan oleh isteri Perdana Menteri Malaysia ketika itu, iaitu Datin Seri Rosmah Mansor. Beliau juga telah dijemput untuk mengadakan demonstrasi dan penerangan mengenai kelingkan di Universiti Malaysia Kelantan (UMK) dengan jemputan khas oleh Prof. Madya Mohamad Najib bin Mohd Nasir dari Fakulti Teknologi Kreatif dan Warisan, Universiti Malaysia Kelantan.

Dengan penglibatan beliau dalam semua kegiatan tersebut, Adiguru Nik Rahimah Nik Idris memberi sumbangan besar dalam mempromosikan seni kraftangan sulaman kelingkan dari dalam dan luar negara. Pada tahun 1993, Nik Rahimah telah diundang untuk mengadakan demonstrasi sulaman kelingkan di Hotel Hayat di Bangkok Thailand semasa beliau mengikuti rombongan Al-Sultan Kelantan, Sultan Ismail Petra sempena mempromosikan Warisan Kelantan (Kelantan Heritage) ke luar negara. Secara tidak langsung, undangan tersebut telah memberi ruang dan peluang kepada beliau untuk memperkenalkan seni sulaman kelingkan Kelantan kepada masyarakat di luar negara.

Pada 20 hingga 21 Mei 2014, bertempat di Manila Hotel, One Rizal Park, 01913 Manila, Filipina sempena program $1^{\text {st }}$ Ceremony to Commemoration of Asian Human Living Treasures yang dianjurkan oleh National Commision for Culture and The Arts (NCCA), Philippines, Nik Rahimah Nik Idris telah menyumbangkan kemahiran dan kepakaran beliau dari segi kesenian dan kemahiran seni pertukangan kraf tradisional, khususnya seni sulaman kelingkan. Penyertaan beliau dalam program tersebut dapat memberikan gambaran sebenar tentang keunikan produk, kekayaan budaya serta kemahiran kraftangan tukang kraf dari Malaysia, sekali gus mempromosikan seni sulaman kelingkan di luar negara. Antara program yang dilaksanakan pada majlis tersebut seperti acara persembahan pameran produk-produk Master Craftman, sesi persidangan dan percambahan idea serta garis panduan dan rujukan yang dapat memberi input dalam memartabatkan seni warisan negara. Selain itu, penyertaan beliau dalam program ini juga dapat menjalin kerjasama dan hubungan baik dengan perwakilan dari negara-negara ASEAN yang turut mengambil bahagian dalam program yang dianjurkan bertujuan untuk memulihara dan memelihara kraf warisan negara masing-masing. 


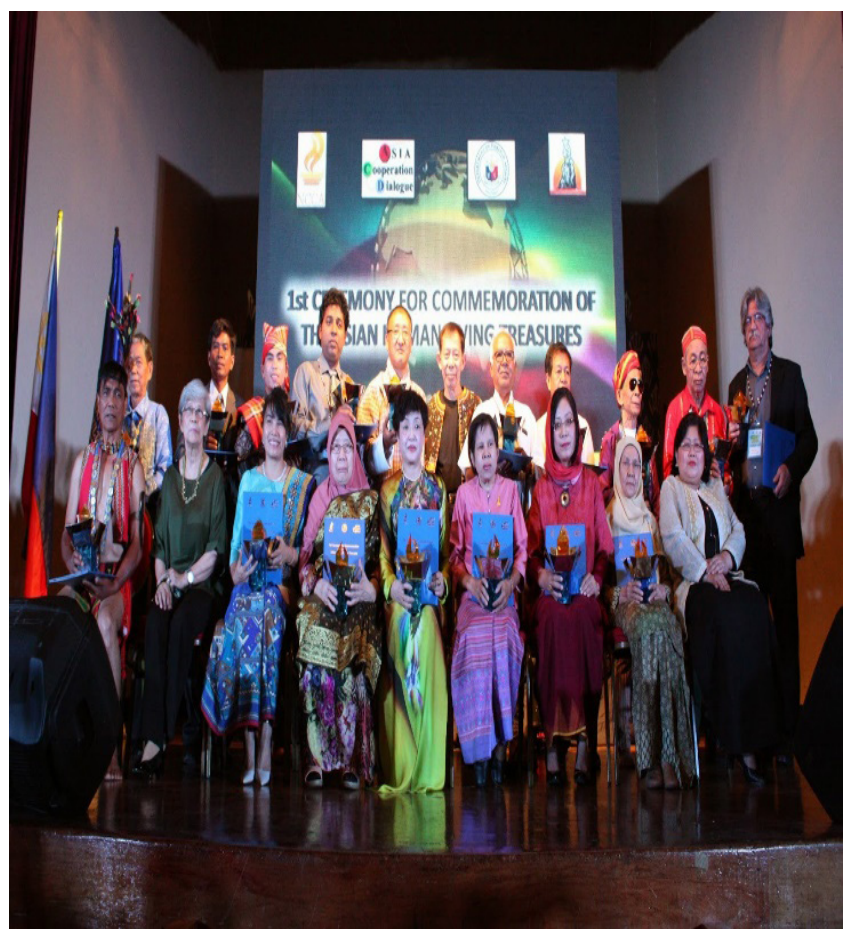

Gambar 7: $1^{\text {st }}$ Ceremony to Commemoration of Asian Human Living Treasure di Manila Filipina (Sumber: Laman web Bahagian Pemuliharaan)

Berdasarkan bukti-bukti yang dikemukakan di atas, ternyata kepakaran Nik Rahimah Nik Idris dalam seni sulaman kelingkan turut diiktiraf dan diakui oleh negara-negara luar. Buktinya, beliau sering diundang ke beberapa negara Asia seperti Thailand, Filipina dan Indonesia untuk memperkenalkan seni sulaman kelingkan ke peringkat antarabangsa. Selain menjadi pakar rujuk dalam seni sulaman kelingkan, usaha yang dilakukannya turut mempromosikan keunikan dan seni warisan negara yang menjadi identiti masyarakat Malaysia umumnya, dan negeri Kelantan khususnya. Melalui usaha-usaha beliau tersebut juga telah memperkenalkan Malaysia di luar negara.

\section{Pengiktirafan dan Penghargaan ke atas Nik Rahimah Nik Idris}

Sumbangan yang tidak ternilai dalam seni kraftangan sulaman kelingkan melayakkan Nik Rahimah Nik Idris mendapat pengiktirafan dan anugerah di peringkat negeri, negara malah peringkat antarabangsa. Antara pengiktirafan tertinggi yang diperoleh oleh beliau ialah Watikah Pelantikan Adiguru Kraf (bidang Kraf Sulaman Kelingkan) oleh Perbadanan Kemajuan Kraftangan Malaysia pada 18 November 2013, yang merupakan pengiktirafan tertinggi diterima oleh beliau pada peringkat kebangsaan oleh kerajaan Malaysia.

Selain itu, Nik Rahimah Nik Idris juga dianugerahi gelaran Adiguru Kraf, iaitu individu yang diberi penghormatan dan pengiktirafan oleh Kerajaan Malaysia sebagai seorang tokoh 
(master craftsmen) setelah mereka menepati kriteria-kriteria seperti mempunyai pengetahuan dan kemahiran yang tinggi dalam bidang kraf kepakarannya atau ahli dalam seni kemahiran ketukangan, penciptaan, penggubahan produk dan pengeluaran barangan kraf warisan bangsa Malaysia. Di samping itu, tokoh yang diberi pengiktiran ini juga telah memainkan peranan penting dalam usaha memulihara dan memelihara seni kraf warisan, di samping berusaha memindahkan kemahiran yang dimiliki kepada kumpulan pelapis agar seni kraf warisan berkenaan berkesinambungan. Seseorang yang diiktiraf sebagai Adiguru kraf juga harus kreatif dan inovatif dalam usaha memajukan dan meningkatkan kualiti produk kraf yang dihasilkan.

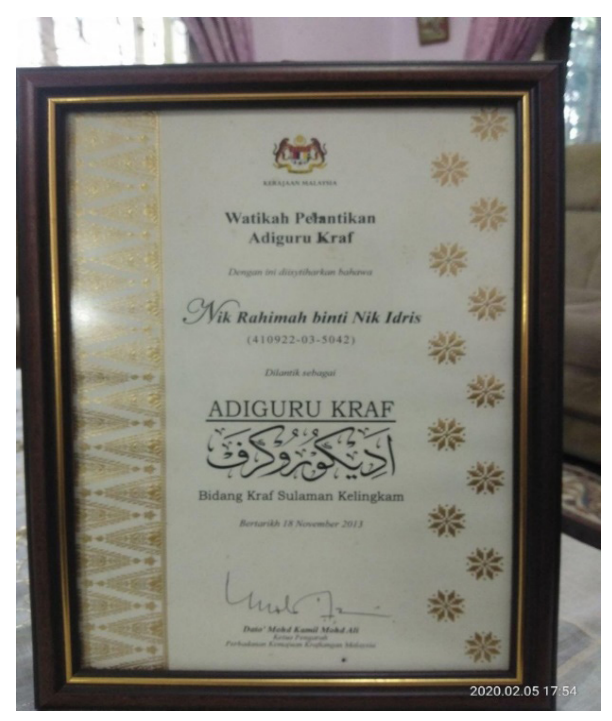

Gambar 8: Watikah Pelantikan Adiguru Kraf (bidang Kraf Sulaman Kelingkam) oleh Perbadanan Kemajuan Kraftangan Malaysia

Pada tahun 1987 beliau telah mendapat tempat kedua dalam pertandingan kategori sulaman yang dianjurkan oleh Perbadanan Kemajuan Kraftangan Malaysia di Kompleks Kraf, Kuala Lumpur.

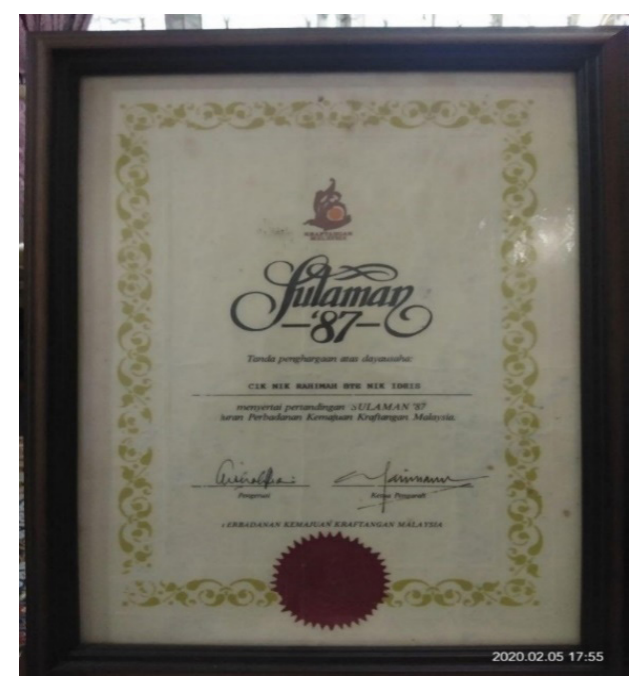

Gambar 9: Tempat Kedua Pertandingan Sulaman anjuran Perbadanan Kemajuan Kraftangan Malaysia 
Pada tahun 2012, beliau menerima Sijil Penghargaan dari Jabatan Muzium Malaysia atas sumbangan beliau sebagai peserta yang turut menjayakan pameran Muzium Tekstil Negara.

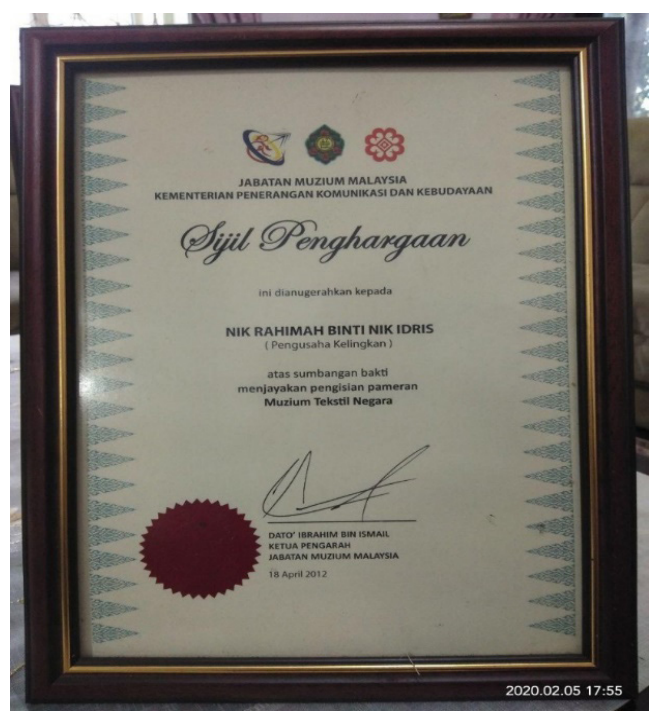

Gambar 10: Sijil Penghargaan dari Jabatan Muzium Malaysia

Pihak Kraftangan Malaysia telah memberi pengiktirafan kepada usahawan kraf tempatan yang banyak memberi sumbangan dalam usaha memulihara, memelihara dan memartabatkan seni kraf warisan. Nik Rahimah Nik Idris merupakan salah seorang penerimanya. Pada tahun 2013, Nik Rahimah Nik Idris telah menerima Penganugerahan Tukang Ulung sempena Promosi Kraf Malaysia (Hari Kraf Kebangsaan 2013) bagi kategori kraf tekstil sulaman kelingkan. Untuk anugerah ini, Nik Rahimah Nik Idris telah menerima hadiah wang tunai RM10 000.00, sijil dan plak penghargaan. Majlis penyampaian anugerah tersebut telah disempurnakan oleh Yang Berhormat Dato’ Seri Utama Dr. Rais Yatim, Menteri Penerangan, Komunikasi dan Kebudayaan.

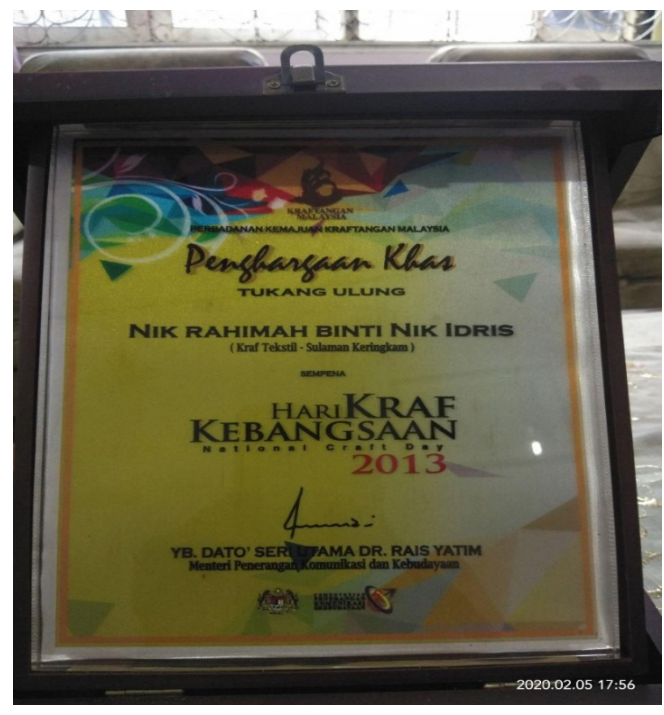

Gambar 11: Sijil Penganugerahan Tukang Ulung 
Selain dalam negara, beliau turut menerima anugerah dari luar negara sekaligus mengharumkan nama Malaysia di pentas antarabangsa. Pada tahun 2014, beliau telah diberi penghormatan atas sumbangannya memartabatkan seni kraftangan sulaman kelingkan di $1^{\text {st }}$ Ceremony to Commemoration of Asian Human Living Treasures yang bertempat di Manila Hotel, One Rizal, Manila, Filipina. Majlis tersebut dianjurkan khusus untuk memberi penghormatan dan penghargaan kepada tokoh-tokoh seni pertukangan kraf/Warisan Orang Hidup daripada kalangan 32 ahli negara anggota Asian Cooperative Dialogue (ACD).

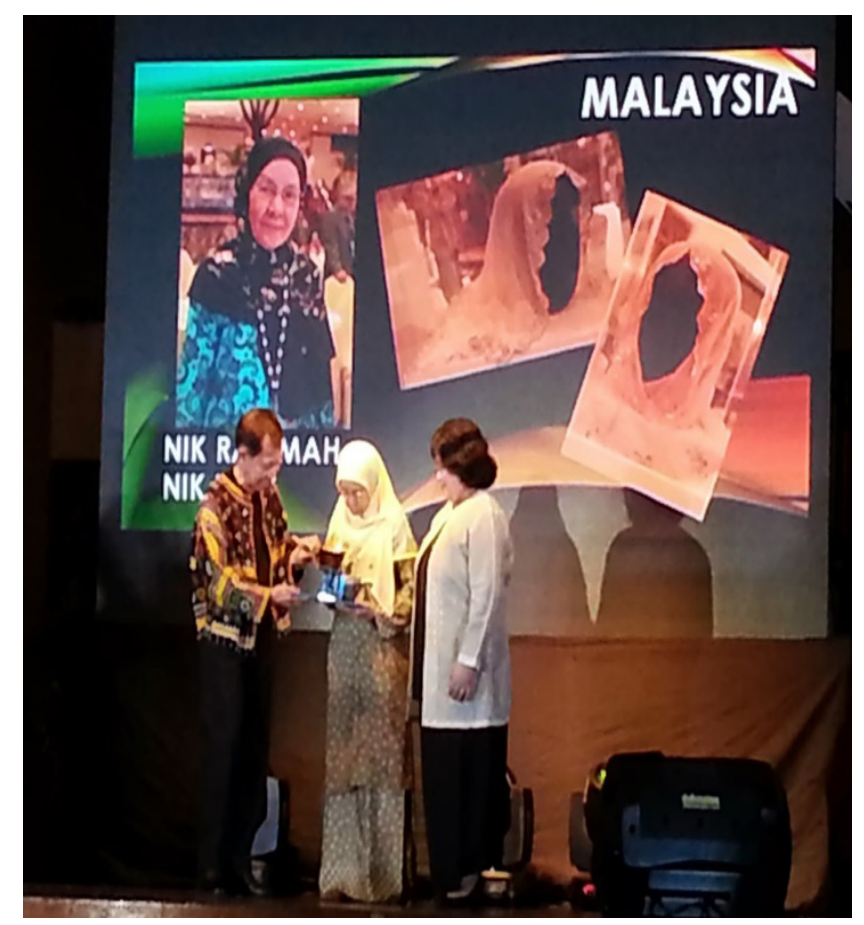

Gambar 12: $1^{\text {st }}$ Ceremony to Commemoration of Asian Human Living Treasure (Sumber: Laman web Bahagian Pemuliharaan) 


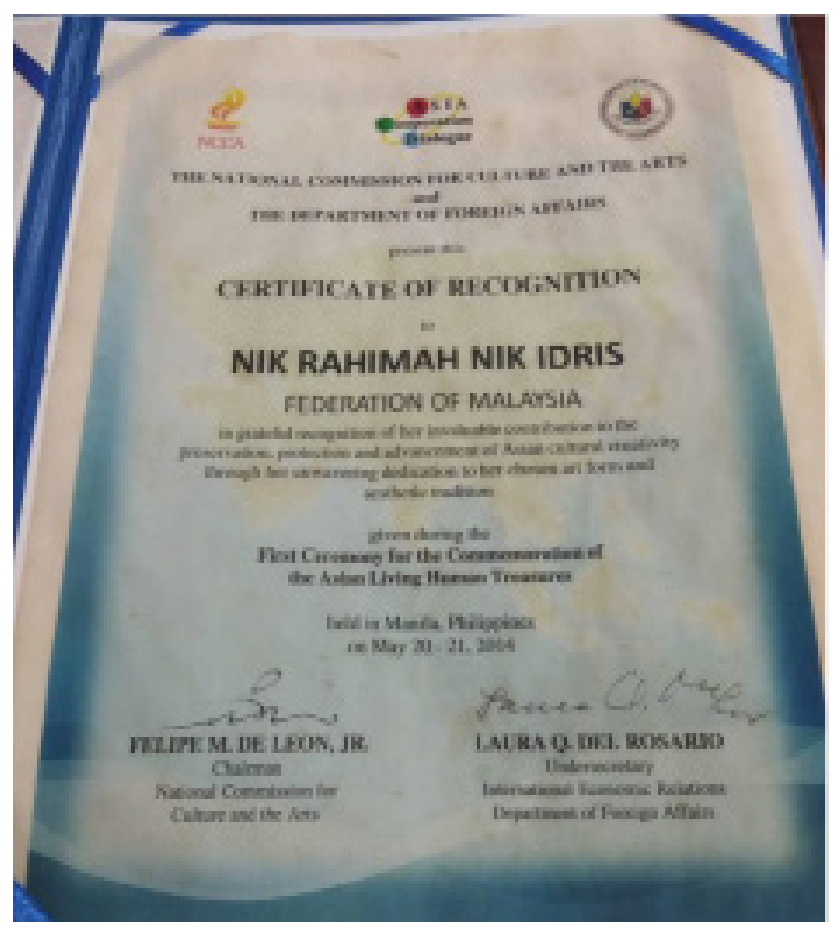

Gambar 13: Sijil Penghargaan pada $1^{\text {st }}$ Ceremony to Commemoration of Asian Human Living Treasures, Manila, Filipina.

Dengan peranan dan sumbangan besar yang telah diberikan, kegiatan dan hasil karya Nik Rahimah Nik Idris telah mendapat liputan oleh media massa tanah air. Beliau telah mendapat liputan melalui media cetak, iaitu Majalah Wanita (1987) ketika memenangi tempat kedua dalam Pertandingan Sulaman 1987. Nik Rahimah Nik Idris juga telah mendapat liputan daripada media penyiaran, antaranya TV3 yang menyiarkan kisah penglibatan Nik Rahimah Nik Idris dalam segmen Wanita Hari Ini (2007) dan Berita RTM 2013 jam 8:00 malam (2007). Pada 5 Mac 2013, beliau ditemu bual oleh pihak akhbar Sinar Harian mengenai teknik-teknik sulaman kelingkan. Paparan tentang penglibatan dan harapan beliau terhadap sulaman kelingkan juga mengisi slot akhbar KOSMO (30 Disember 2019). Perhatian dan pendokumentasian yang dilakukan oleh pihak media massa ini secara tidak langsung telah memperkenalkan sulaman kelingkan dan mengangkat ketokohan Nik Rahimah Nik Idris. Secara tidak langsung turut membantu menjelaskan kepentingan peranan dan sumbangan yang telah diberikan oleh tokoh penyulam kelingkan ini terhadap individu, masyarakat dan industri kreatif negara.

\section{Kesimpulan}

Peranan, jasa, dan sumbangan Adiguru Nik Rahmah Nik Idris dalam memartabatkan dan memelihara seni sulaman kelingkan adalah amat besar. Beliau telah menggunakan hampir seluruh usia dan kehidupannya dalam kegiatan menyulam, memelihara dan memartabatkan kedudukan sulaman kelingkan dalam dan luar negara. Peranan dan sumbangan beliau dapat disimpulkan kepada tiga kategori utama, iaitu peranan dan sumbangan secara individu, peranan dan sumbangan 
dalam masyarakat, dan peranan dan sumbangan dalam industri. Sebagai menghargai jasa, peranan dan sumbangan tersebut, Nik Rahimah Nik Idris telah menerima pelbagai bentuk penghargaan dan pengiktirafan dari pelbagai pihak di dalam dan luar negara. Beliau layak diangkat sebagai tokoh ulung seni kraftangan warisan negara yang ulung khususnya dalam sulaman kelingkan di Kelantan khasnya dan di Malaysia amnya. Usaha pembangunan kraf negara, sokongan dan kerjasama daripada semua pihak amat diperlukan, terutamanya dalam menyediakan kemudahan, kelengkapan peralatan, kewangan dan moral kepada tukang-tukang ulung seni kraf. Sokongan dan kerjasama yang diberikan membantu mereka terus berbakti dan mencurahkan ilmu kepakaran kepada generasi muda supaya seni kraftangan, khususnya seni sulaman kelingkan terus terpelihara dan dapat dipopularkan kembali dalam kalangan generasi pada hari ini.

Penghargaan: Kajian ini adalah hasil penyelidikan daripada Geran Penyelidikan Fakulti (GPF004K-2018) pembiayaan dana Universiti Penyelidikan (RU) 2018, Universiti Malaya.

\section{Rujukan}

Azah Aziz. (2009). Rupa dan gaya: Busana Melayu. Bangi, Selangor: Penerbit Universiti Kebangsaan Malaysia.

Azran Arip. (2010). Sulaman warisan Sarawak: Tudung Keringkam. Kuching, Sarawak: Perbadanan Kemajuan Kraftangan Malaysia Cawangan Sarawak.

Bahagian Pemuliharaan. (2012). Adiguru kaf sulaman Keringkam. 23 April 2012. Retrieved from http://tokohadiguru.blogspot.com/2012/04/adiguru-kraf-sulaman-keringkam.html.

Bahagian Pemuliharaan Kraftangan Malaysia. (2011). Pengiktirafan tokoh: Biodata Nik Rahimah binti Nik Idris. Retrieved from http://tokohadiguru.blogspot.com/2013/10/biodata-nikrahimah-binti-nik-idris.html.

Bahagian Pemuliharaan. (2014). $1^{\text {st }}$ Ceremony to Commemoration of Asian Human Living Treasures. 11 Jun 2014. Retrieved from http://pemuliharaankraf.blogspot.com/2014/06/1stceremony-to-commemoration-of-asian.html.

Maxwell, Robyn. (1994). Textiles of South East Asia: Tradition, trade and transformation. Kuala Lumpur: Australian National Gallery.

Perbadanan Muzium Negeri Kelantan. (2011). Muzium Adat Istiadat: Sejarah Bangunan. 19 Ogos 2011. Retrieved from https:/web.archive.org/web/20110819085224/http://kelantan. muzium.net/v2/index.php?option=com_content\&task=view\&id=19\&Itemid=55.

Siti Zainol Ismail. (2010). Seni Sulaman Kelingkan Keringkam Sarawak. Seni Rupa Alam Melayu [Online]. Retrieved from http://senirupasiti.blogspot.com/2010/01/seni-sulaman-kelingkankeringkam.html. 
Suhana Sarkawi \& Norhayati Ab. Rahman. (2014). Selayah Keringkam dan Selayah Manto: Sulam Budaya Melayu Sarawak (Malaysia) dan Melayu Daik (Indonesia). Prosiding Persidangan Persidangan Kebangsaan Kecemerlangan Melayu Pertama. Hotel Armada Petaling Jaya, 2.

Suhana Sarkawi \& Norhayati Ab. Rahman. (2016). Jejak sulaman kelingkan di Malaysia dan Indonesia. Jurnal Pengajian Melayu/Journal of Malay Studies (JOMAS), Universiti Malaya, Jil. 27, 45-69.

Syaherah Mustafa. (2019). Nilai kelingkam bagaikan emas. Retrieved from https:/www.bharian. com.my/wanita/fesyen/2019/07/588048/nilai-kelingkan-bagaikan-emas.

Zubaidah Ibrahim. (2015). "Nik Rahimah mahu kelingkam dikenali” dalam akhbar KOSMO, 30 Disember, pp. 21-13.

\section{Temu bual}

Puan Nik Rahimah Nik Idris dan pembantunya Nik Marhamah Nik Megat, ditemu bual pada 1 Februari 2019 di rumah cucunya di USJ Heights, Subang Jaya, jam 3:00 petang.

Puan Robitah Hashim ditemu bual pada 8 Februari 2019, bertempat di Zinta Trading (bengkel penyulamannya), Lot 154 Jalan Masjid Tok Uban, Pasir Mas Kelantan, jam 3:00 petang.

Puan Nik Rahimah Nik Idris dan pembantunya Nik Marhamah Nik Megat, ditemu bual di rumahnya di Kampung Uda Murni, Kota Bharu, pada 5 Februari 2020, jam 5:00 petang.

Puan Nik Rahimah Nik Idris dan pembantunya Nik Marhamah Nik Megat, ditemu bual di Kompleks Kraf Negara, Jalan Conley Kuala Lumpur, pada 6 Mac 2020, jam 4:00 petang. 